the needs and aspirations of the people, and it can with truth be said that there is not one part of it which does not owe much to the imagination, interests and effort of Tom Barton'.

\title{
Evolution Politique du Congo Belge
}

Le premier cycle des Journées Inter-universitaires d'Etudes Coloniales (Bruxelles, 29 et 30 décembre 1952), résultat d'une entente entre les délégués des quatre universités du pays et de l'Institut Universitaire des Territoires d'Outre-Mer, avait pris pour thème l'évolution politique du Congo Belge. Trois rapporteurs avaient été désignés: M. A. Marzorati traitant de 'L'évolution constitutionnelle du Congo'; M. Malengreau examinant 'La participation des indigènes à la vie politique' et $M$. G. Vanderkerken considérant le 'Développement de l'économie indigène congolaise'.

\section{Economic Conference at Achimota}

A cONFERENCE organized by the West African Institute for Social and Economic Research was held at Achimota in April 1953. In addition to representatives from the University Colleges of Fourah Bay, Achimota, and Ibadan, Professor Gaston Leduc of the University of Paris, M. Jean Ehrhard, Director General of Finance, A.O.F., and the Directors of Economic Affairs from the Ivory Coast, Dahomey, and Togo, were present.

Subjects on which papers were presented and discussed included industrial relations in West Africa, use of local resources in economic development, inflation in underdeveloped territories, the practical aspects of social and economic research, as well as problems peculiar to individual West African territories. The hope was expressed that such conferences, including representatives of all countries with economic responsibilities in West Africa, might be further developed and that the next meeting might be held in French territory.

\section{Native Lav}

Volume III, no. 2 of Civilisations, the organ of the Institut International des Civilisations Différents (INCIDI), is devoted to a discussion of the personal law of natives (statut personnel des autochtones) in the Belgian Congo, in British Colonial Territories, in French Africa, and in Indonesia. Arthur Phillips discusses the 'legal dualism' in certain British colonial territories arising from the co-existence of indigenous customary law and a system based on English law-an administrative policy which he traces back to William the Conqueror. M. A. Sohier deals with the Belgian Congo, M. Jean Chabas with French Africa, M. Pieters-Gill with Indonesia. The discussion is analysed and concluded by Dr. Kollewyn of Leyden.

\section{East African Institute of Social Research}

A REPORT of the work carried out under the direction of the Institute during the three years $1950-3$ includes an account of the aims and objects of the Institute as well as details of the various projects now in progress or completed since its foundation in 1952 . These are classified as (a) Basic ethnographic studies; (b) Comparative research in African sociology; $(c)$ Special surveys; (d) Sociological projects; $(e)$ Economics; $(f)$ Psychological research; (g) Linguistic research.

The various studies described have been carried out by the research fellows of the Institute and by independent research workers financed by other bodies and placed under the supervision of the Institute during their time in E. Africa. A short summary is given of 
each project, with indications of the ecological background, the specific object of the study, and plans for publication of the results.

An interesting section of the report discusses experiments in research methods, particularly in relation to the possibilities of combining detailed, small-scale investigation with sampling methods, and the study of a wide range of variation within one culture. The organization of comparative studies and co-operation between different disciplines are two methods of study with which the Institute is particularly concerned.

Among the conferences organized by the Institute (some of which have already been noted in this journal) of particular interest is a joint conference held in February 1953 and attended by seven delegates from IRSAC and nine from the East African Institute. This conference coincided with a meeting of experts in the social sciences convened by the Council for Scientific Research in Africa South of the Sahara (C.S.A.), and observers attending that meeting took part in many of the sessions of the conference.

The Institute proposes to publish the work of its fellows in a series of papers called ' East African Studies ', to be published by the East African Literature Bureau. Monographs and comparative studies will be published in book form.

\section{African Music}

Aт a joint meeting of the Royal Africa Society, the Royal Empire Society, and the International African Institute, held in London on 6 October 1953, with Sir John Maud in the Chair, Mr. Hugh Tracey, founder and director of the African Music Society and author of Chopi Musicians, gave a lecture on African Music. Mr. Tracey spoke of the powerful integrative force of music and dance in African societies. All aspects of the life of the individual or the group-love, war, friendship, politics, domestic strife, as well as the community's moral judgements-are expressed in music and dance, and in these activities the African truly re-creates himself. For all those who wish to understand the African and to assist in his integration into the life of the modern world, nothing is more worthy of systematic and sympathetic study than African music and dance. The wide range of forms and of emotional content to be found in African music was strikingly illustrated by records, made from some of Mr. Tracey's own recordings. These included a melody of great charm and gaiety played on a flute by a Hima herd-boy, a vigorous choral number from Sukumaland, an intermezzo played by one of the famous Chopi xylophone orchestras, a legend from Buganda chanted by a local bard, and a concerted item from Southern Congo played by drums and xylophones, in which the peculiar snarl of weighted drums combined with the occasional high-pitched wail of voices to produce an intensely dramatic effect.

Mr. Tracey also showed a film of the remarkable dances performed by Tutsi dancers in Ruanda-Urundi; the dancers, most of them well over $6 \mathrm{ft}$. tall, displayed a sinuous grace of movement, enhanced by their mane-like head-dresses of banana fibre. 